\title{
フランスにおける最近の日本酒事情について
}

黒田利朗氏は, 1981 年にパリに翻訳やビジネス関連調査を行うシンクタンク会社 KSM を設立され，こ の分野では長く活躍されておられますが, 2004 年から日本食レストラン（現在 3 軒）, 2007 年から日本食 材・調味料, 酒類の輸入販売を行うワークショップ・イセを始められました。ワークショップ・イセでは 「ホンモノの食材を通じて日本の風味を伝える」をコンセプトに, 欧州への日本の生活文化の発信に取り組 んでおられます。氏のフランスでの長い経験と交友関係を生かした, ジャーナリスト, ソムリエ, 飲食業関 係者を対象とした日本酒試飲会の取り組み, また, ビジネス経験に基づくアルコール関連事情の分析等から, 今回大変新鮮かつ価値のある報告をいただいております。

\section{黒田利 朗}

\section{はじめに}

筆者は, パリで日本食レストラン経営と平行し，日 本食品, 日本酒を輸入販売（イセ）している。フラン ス文化圈での生活は 40 年と長くなったが,「食」との 出会いは偶然かつ最近である。日本食レストランを最 初にオープンしたのが 8 年前, 日本酒・日本食品販売 は 5 年前に始めた。料理人の世界の独特のルールに驚 き, 食品商社, フォワダーなど仕事上のパートナーの 「専門家的」ロジックに困惑しつつ職業としての食の 迷宮に迷い込んだ。手探り状態は今も続いている。

本稿は専門家の手になるものではなく, 新米の日本 酒「実践」者の断片的感想である。たた，フランスと いう遠いところで日本酒を扱うことで日本では聞こえ ない声も知らずに聞いているかもしれない。パリから の岡目で何目かでも拾うことができれば幸いである。

\section{A. 日本酒に関するいくつかの誤解}

フランスでも日本酒を「Saké」と呼ぶが, 残念な ことに「サケ」は誤解にまみれており，しばしばネガ ティブなイメージを伴っている。

日本体験のない平均的フランス人は「サケ」は匂い が強く酒精ぷんぷんの「腸捻り (tord-boyaux)」だと 思い込んでいる。高いバラ様芳香がある中国の「白 酒」である。
在仏中国人は 60 万人と推定され, 中華レストラン はフランスの津々浦々に赤ぼんぼりを揭げ, 安価かつ エキゾチックな食事をフランス人に提供している。そ して, 多くの中華レストランでは, 食事終了のアナウ ンスのかわりに, 主人がアジア風微笑を口元にたたえ て,「Puis je vous offrir du saké? = お开ヶをサービ スさせていただきたいのですが...」と無料で食後酒を 提供する「美風」が存在する。バラ香とノドを焦がす 酒精が忘れがたい印象で食事を締めくくり, 猪口の底 の拡大レンズの向こう側に肌もあらわな東洋美人が微 笑んでいることもあり「サケ」という言葉は, ますま すフランス人の脳髄に明確に刻み込まれることになる。

サケ =中国産蒸留酒, これが第一の誤解である。

フランスで日本料理の看板を出す店の多くで, 飲料 は有料の拄茶 (粉茶, 4 ユーロ程度) か, 有名日本ブ ランドのビールが好んで提供されている。たまには 「サケ」なるものも飲んでみようと考える風流な客も いる。供される「サケ」は米国製「清酒」であること も少なくない。「日本通」を自認するフランス人には, 「サケとは熱して飲むもの」と思い込んでいるひとも 多い。

サケ = 熱して飲む経済酒，これが第二の誤解である。 フランスはつまり, 日本酒に関して無理解と誤解に

Sake in France : Importer's Observations Toshiro Kuroda (Issé \& Cie) 
満ちた荒野であり，日本酒の福音を届けるのは並大抵 のことではない。なにしろフランス人は, 自国流美食 こそが (生活) 文化の土台だと堅く信じている。つと に有名な「フランスの中華思想」は死に絶えて扮らず, 思想や科学, 外交などでは地盤沈下の激しいフランス だが, こと飲食にかぎると「中華」思想は今も現役, フランス料理をユネスコの無形文化遺産に登録するこ とにも成功してしまった。

\section{B. フランス人と飲酒}

フランス人に日本酒を飲んでもらうには, フランス の生活・食文化の文脈の中に「サケ」の場所を探しだ さねばならないが, まずフランス人と酒, 飲料の関係 を考えよう。

\section{1. フランス人は酒飲み（だった?）}

フランス人は大の酒好きで，酒に寛容だった。まだ フランス新幹線（TGV）が走っていなかった 30 年以 上前の話になる。秘書室, 理容室が付いていて食堂車 ではフルコースのフランス料理が供されていた当時の 花形列車ル・ミストラル（パリ・リヨン・マルセイユ 間）の機関士をパリ・リヨン駅で見かけたが, 弁当と ワインのビンを抱えて機関車運転室に昇るところだっ
た。ル・ミストラルは, 日本の新幹線が登場するまで 世界の速度記録を持つ高速列車だったが, 機関士が運 転席でワイン付きの昼食をとっても誰も驚かなかった。 ちなみに, 職場での飲酒がフランスではじめて規制 （禁止ではない）されたのは1973年であり, 飲酒運転 に罰金が課されるようになったのは 1994 年以降であ る。

酒好きなフランス人の飲酒量が減少している。15 才以上のフランス人の年間アルコール消費量は 12.3 リットル（100\%アルコールに換算，2008 年）で, 日 本人の 7.5 リット（同）より多いが, 40 年前の 1970 年にはフランス人は 20.4 リトル飲んでいた。 蛮カラなゴロワ人気質に変質が起こっているらしい。

\section{2. フランス人のワイン消費が後退}

仏全国葡萄ワイン公社（ONIVINS）の 2000 年定点 調査 $^{1}$ よると, 14 才以上のフランス人の $88 \%$ 以上が アルコール飲料を消費しているが，27\%が習慣的（ほ ぼ每日）飲酒者で，39\%は頻繁な，33\%が機会的飲酒 者となっている。習慣的飲酒者, 頻繁な飲酒者の摂取 飲料はワインが主たるもので, 消費アルコール総量の 60\%がワインである。フランスの酒飲みには「酒イコ

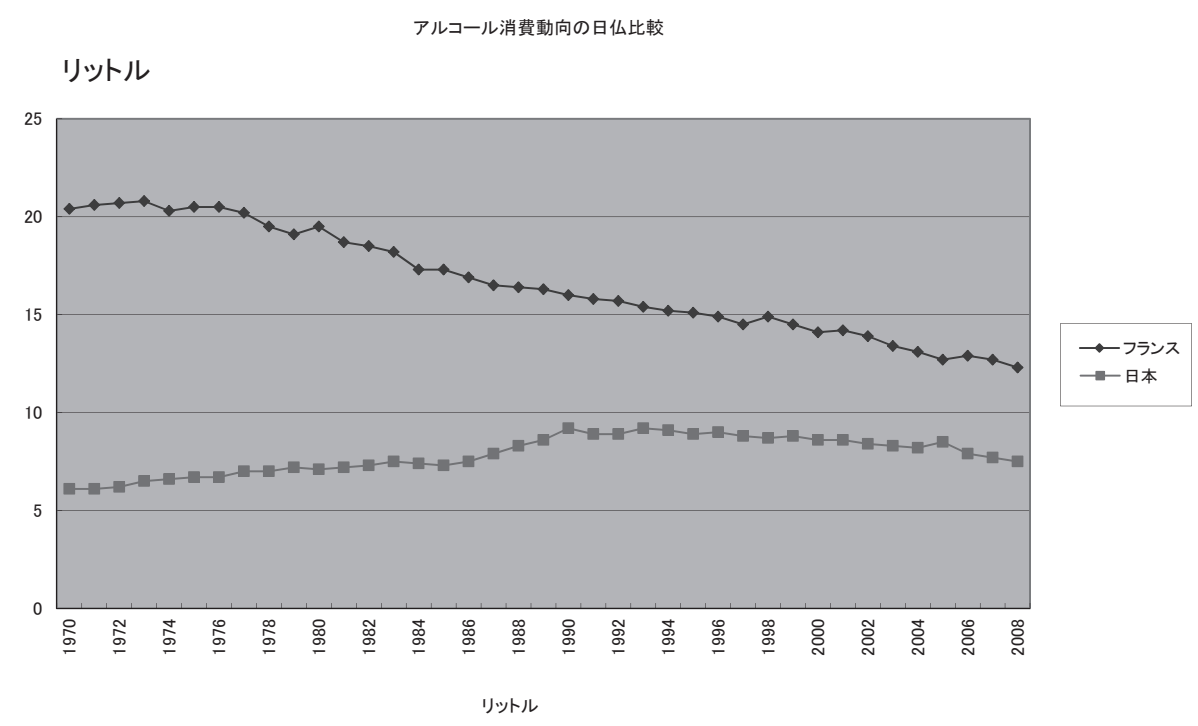

第 1 図 アルコール消費量動向の日仏比較

出所 : who, insee http://www.insee.fr/fr/themes/tableau.asp?ref_id = NATTEF06219\&reg_id = 0

1 http://www.onivins.fr/pdfs/851.pdf 
ール，ワイン」ということになる。

ところが, フランス人のアルコール消費の聥減傾向 （表1）はワイン消費減少が主因であり，ビール，ス ピリッツなど他はほぼ横ばい。「国酒」ワインに何が おこっているのだろうか。

\section{3. ミネラル水, ソフトドリンクの台頭}

水と油は喧嘩をするが, フランスでは水と酒も仲が 良くない。

ONIVINS 調査によると, 習慣的飲料の首位はワイ ンではなく水でフランス人の $64 \%$ がミネラル水を習 慣的に摂取している。機会的消費を合わせた浸透率は 81\%。また, ソフトドリンクの浸透率は $84 \%$ とミネ ラル水よりも高いが，習慣的消費者は $40 \%$ にとどま る。そしてワインの浸透率は $70 \%$ ，習慣的消費者の 比率は $22 \%$ でしかない。

習慣的飲料は基本的に食中飲料で，長くワインがそ の座を占めていたが，1995 年以降はミネラル水に首 位を奪われた。

また, ソフトドリンクも食中飲料として比率を高め ている。冷たく甘いソーダや果汁を食事中に飲むのは 主に若者だが，年を重ねオジさんになるとワインに回 帰するのだろうか? 。

\section{4. フランス人は普段酒を飲まなくなった}

上記調查は, フランス人がワインを飲むのは「ハ レ」の機会だとしている。

レストラン, 知人宅での食事では $90 \%$ がワインを 飲むと回答し，70\%は外食時はかならずワインを飲む と答えている。接待, 出張時の外食も「ハレ」の食事 であり，70\%がワインを飲んでいる。一方，自宅の食 事，職場の昼食でワインを飲むフランス人は少数派に なっている。

\section{5. 若者のワイン離れ}

フランス人の日常生活からほろ酔い状態の追放が進 みミネラル水が台頭しワイン消費が減ってきたが，ワ イン離れが顕著なのは若者層である。15-24才層はフ ランスの飲酒年齢人口（15才以上）の $17 \%$ を占める が，ワインの消費量では $5 \%$ でしかない。逆に65才 以上の高齢者は飲酒年齢人口の $19 \%$ だがワイン消費 量では 30\%のウエイトを占める。また, 15-24才層の ワイン消費量は年間 18 リットルだが，45-74才層では 90 リットルとなる。同じ人種だとは思えないほどの ギャップだ。

習慣的飲酒では高齢化はさらに顕著で, 1980 年に はワイン人口中習慣的飲酒者の比率が半数を超えるの

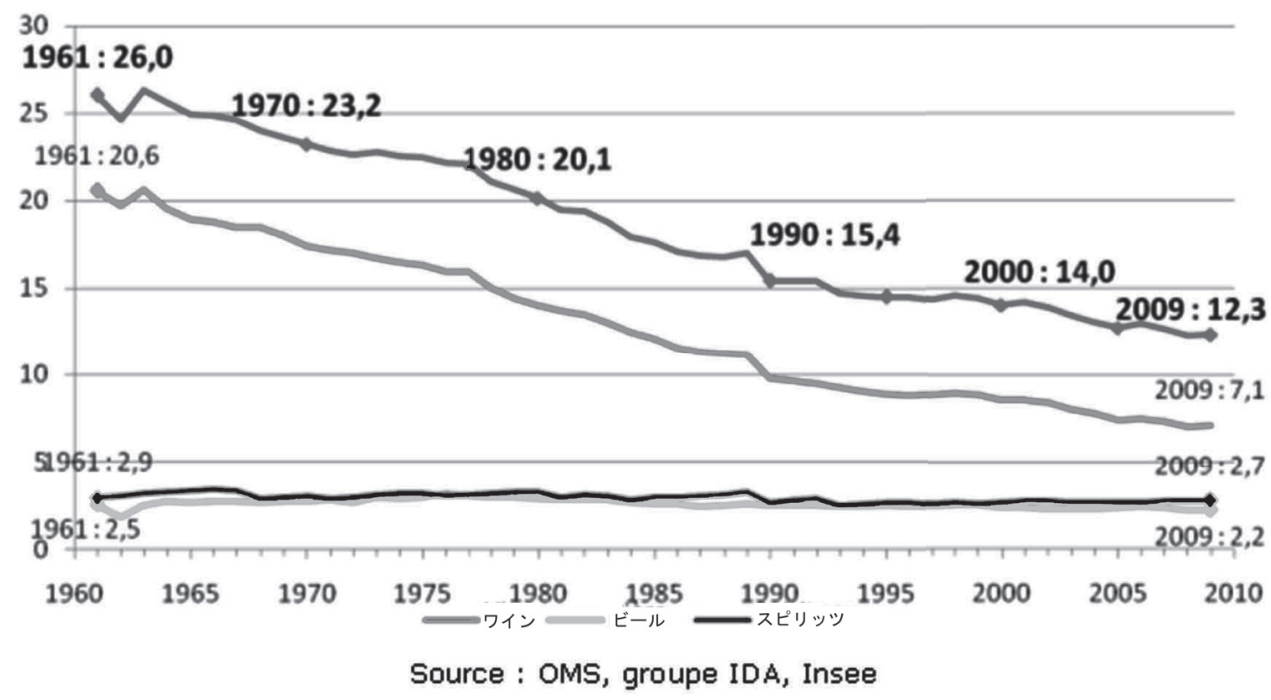

第 2 図 アルコール販売量の推移(15才以上国民一人当り)

単位：リットル (100\%アルコールに換算)

出所：世界保険機構, IDA, 仏国立経済統計研究所 


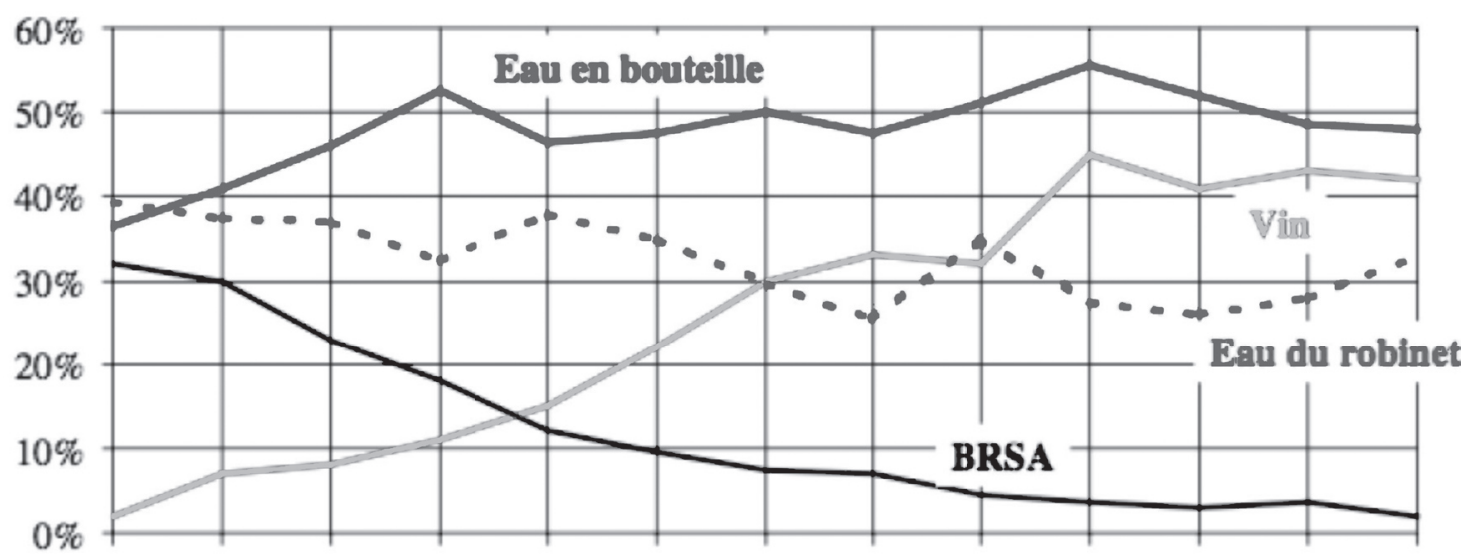

15- 20- 25- $30-\quad 35-\quad 40-\quad 45-\quad 50-\quad 55-\quad 60-\quad 65-70-75$ et $\begin{array}{lllllllllllll}19 & 24 & 29 & 34 & 39 & 44 & 49 & 54 & 59 & 64 & 69 & 74 & +\end{array}$

ミネラル水 (Eau en bouteille)

ワイン (Vin)

水道水 (Eau du robinet)

ソフトドリンク (BRSA)

第 3 図＼cjkstart食中飲料と年齢層 $(2000$ 年)

出所 : http://www.onivins.fr/pdfs/813.pdf

15-19才のワイン飲酒頻度の推移

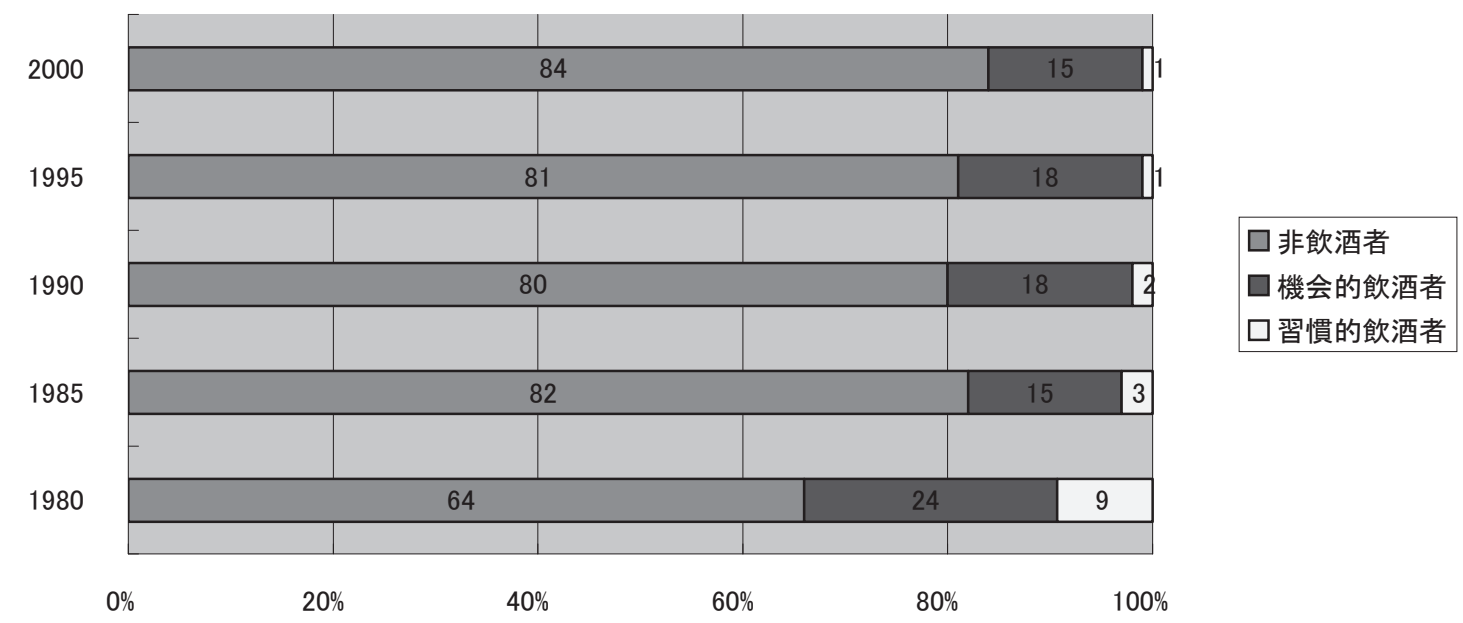

第 4 図 若者のワイン飲酒頻度 (2000 年)

出所 : http://www.onivins.fr/pdfs/813.pdf 
は 25 才以上だったが, 1990 年では 40 才以上になり, 2000 年の調査では 60 才以上になってしまった。ワイ ンはオジさんの飲み物ですらなくおじいさんの飲み物 になったかの観がある。

ちなみに, ワイン消費行動に関しては, 2011 年 7 月にポルトで開催された国際ぶどう・ワイン機構 (OIV) 第 34 回大会でフランスの調査報告 ${ }^{2}$ が発表さ れた。報告では, ワイン消費者を以下の年齢層でセグ メント化し，意識が異なることを明らかにしている。 セグメント $1:$ ヘリテージ世代（65才以上） セグメント $2: \mathrm{X} 世$ 代またはネットワーク世 代 (30-40才)

セグメント 3：Y世代またはモザイク世代 (18-30才)

\section{・ワインを飲む機会}

全セグメントで, ワインは友人との楽しい時間に貢 献すると認めているが，レギュラーにワインを楽しむ はX世代で，お祝いやパーティーなど「ハレ」の機 会にワインを飲む。Y世代は, 例外的にしかワインを 飲まず，かつ，「集飲（分かち合って飲む）する」と いう回答は「ワイン・マニア」に限定される。コミュ ニケーションの媒介役としてのワインの機能が失われ つつあることがわかる。

\section{・ワインは文化的遺産}

すべてのセグメントがワインから, 美食, 文化を想 起すると答え, ヘリテージ世代はテロワール，宗教的 慣行, 地方色豊かなワイン造りの伝統などを想起して いる。X世代は，ワインの呼称の多様さを面倒と考え， ワインを知るには膨大な知識が必要だと指摘。Y世代 はワインの呼称が多すぎて, ワインの世界は「高級で 複雑」と敬遠している。

・ワインの選択

ヘリテージ世代はワインの選択に困難を感じない。 常時同じワインを飲み, 多くの場合はテーブル・ワイ ン級のワインを選んでいる。X世代は, ワイン選択は
「厄介」で，「ワインを飲むのはエリート」と回答。そ してY世代は, ワイン選択が容易になるもっとモダ ンなボトル表示を求めている。

・ワインと健康

ヘリテージ世代にはワインは健康な飲み物と認識さ れているが, 若い世代はアルコールの危険性（飲酒運 転, 日常生活）により敏感で, 特に若い女性にこの傾 向が強い。

\section{C. フランスにおける日本酒}

\section{1. フランス市場における日本酒の問題}

フランス人が食事とともににワインを飲まなくなっ ていることは, 同じ醉造食中酒である日本酒の浸透に はネガティブな要素だが, さらに，日本酒については， 誤解があることを最初に指摘した。

・日本酒はバラ香のする蒸留酒である

・日本酒は熱燗で飲む経済酒である

5 年前に日本酒輸入販売を始めたときに, 日本酒に 関する誤解払拭がまず必要と考え,「サケ」というス ポイルされた言葉に,「Saké Ginjô」という言葉を対 置した。「サケ・ギンジョー」を日本酒本来の価值を 取り返すための「旗」にコミュニケーションの努力を してきた。また, 美味しさを体験してらうには試飲が 不可欠なことは自明で,

・すべての来店顧客に無料試飲をすすめる

·定期的な有料試飲会を開催する

·SIAL，SIA，SIRAH など食品見本市に出展し試飲 してもらう

という活動を行ってきた。

過去 5 年間で約 3 万人程度のフランス人に「サケ・ ギンジョー」を試飲してもらった事になる。

また，オピニオンリーダーに日本酒「伝道師」にな ってもらうべく, ジャーナリスト, 食評論家, 有力シ エフ\&ソムリエなどに積極的にアプローチした。

2 ポルト大会での報告概要：http://www.winepaper.fr/generation-y-consomme-rarement-vin-1364

報告書: “The representations of wine in France from generation to generation: a dual generation gap”, 著 者:Thierry Lorey, Pascal Poutet, in International Journal of Entrepreneurship and Small Business, Volume 13, Issue 2, p162-180 (2011) 
・世界最優秀ソムリエのオリビエ・プシエ氏などに日 本で蔵元巡りをしてもらった。

・話題性のあるレストランで日本酒とフレンチ料理を 合わせた食事会を開催してきた（C.3. 参照）。

フランス・ワイン界でもっとも権威ある専門月刊誌 レヴュー・ド・ヴァン・ドフランス ${ }^{3}$, フランス・料 理界の新しい潮流を反映する料理月刊誌ゴー・エ・ミ オ ${ }^{4}$ などで日本酒について好意的記事が揭載されるこ とにもつながった。

また，仏閣僚，日本大使なども参加されるパリ・ソ ムリエ協会のガラ・ディナー（2010年 10 月 9 日，レ ストラン「プレカトラン」) では, プシエ氏が選択し た日本酒がサービスされる。

試飲した数多くのフランス人が日本酒についてもっ た感想について, 一言。

·否定的反応

高齢のワイン習慣的飲酒者は日本酒を「とらえどこ ろがない」と感じるようだ。酸味, 樽味がない日本酒 は「茫洋としていて評価の手がかりがない」という。

·肯定的反応

ソムリエ・シェフの多くは, 純米大吟醉, 生もと, 山廃系の日本酒を「余韻が長い」,「グラ（油脂）があ る(テクスチャーに艶がある)」,「複雑性が好もし い」などと評価。

一般ワイン愛好家は, 大吟醕, 生酒, にごりなどに
敏感に反応。新奇なものを喜ぶ。

女性は高い香りが好きだ。吟醸酒中に良いウイキョ ウの香りがするとのコメントもある。低アルコール酒 を飲みやすいと評価する女性が多い。

\section{・フランス人に共通する点}

吟䁔香を楽しんでもらうため, イセではワイン試飲 用 INAO グラスを使用しているが，なかなかグラス を口に付けず長く香りを楽しむ傾向がある。日本酒に 比べて旨味成分の少ないワインの味わいでは香りに重 心がかかっているからだろうか。口にしてからも， 「白い花」,「森の下草」,「ライチ」など香りをべース にした味わい表現が頻出する。

以下に，試飲した顧客類型別に，日本酒タイプ毎の 好感度を（ゼロ）から $(+++)$ までの四段階評価で 表にしてみた。

試飲好感度は高いが, 日本酒が伝統ある醸造酒とし て「ワインと比肩できる食中酒」として認知されるに はいくつかの問題が残っている。

\section{第一は価格。}

最大級の訪問者数を誇る電商サイト CDISCOUNT (大手流通カルフール众下) では, ロバート・パーカ ーが91点を付けたロワールのミュスカデ「Domaine du Haut Bourg “Les Enclos” 2009」が 3.99 ユーロで

第 1 表 日本酒タイプ毎の好感度

\begin{tabular}{|c|c|c|c|c|c|}
\hline & $\begin{array}{l}\text { ソムリエ } \\
\text { \&シェフ } \\
\end{array}$ & \begin{tabular}{|c|c|}
$\begin{array}{c}\text { ワイン愛好家 } \\
\text { 高齢 }\end{array}$ \\
\end{tabular} & $\begin{array}{c}\text { ワイン愛好家 } \\
\text { 若壮年 }\end{array}$ & 一般男性 & 女性 \\
\hline 大吟醉・吟醉 & ++ & & ++ & ++ & ++ \\
\hline 生酒 & + & & +++ & ++ & + \\
\hline 生もと山廃 & +++ & + & ++ & & \\
\hline 低アルコール & + & & + & ++ & ++ \\
\hline ニゴリ酒 & + & & & +++ & + \\
\hline 発泡酒 & ++ & & & + & ++ \\
\hline 全敖酒 & ++ & + & + & & \\
\hline
\end{tabular}

3 “L'empire des sens, sushi et saké ginjô”, La revue du vin de France, 548 号, 2011 年 2 月, P103

4 “SAKÉ, Nectar des Dieux”, Gault\&Millau Magazine,2011 年 4-5 月, P126 
売られ，ブルゴーニュの銘醸酒ムルソー（白）「Michel Picard “Les Corbins" Meursault 2007」が 13.9 ユーロで買える。

一方, イセの日本酒店頭小売価格は, ワインボトル とほぼ同量の 4 合瓶の純米吟䣬・大吟醉酒が 35 から 70 ユーロとなり価格にかなり乘離がある。フランス 人が納得できる日本酒の価值を提示しなければならな い。

第二は味わい。

風味については好感されている。しかし，フランス 人が尊いとするワインには何処かに「険」があり，そ の険しさを料理の見えない弱点と重ねるときにはじめ て「娟」が生まれ，これをフランス人は「マリアージ ユ」と呼ぶ。フランス人がうつくしく，しなやか （娟）だと感じるのは，強い酸とタンニンで支えられ るワインの味わいの構造と, 料理の味覚構造のゆがみ が美しい非対称を作り出すときではないか。乱調の美 である。ワインには, 料理と喧嘩をしてでも「味わ い」を高みに導く野趣に満ちたものがある。

これに比べ，スタンダードな（そんなものがあると すればだが）日本酒は，水の粋にも似てその美点は正 調の美しさにある。フランス人にはこの美しい味わい が時としてとらえどころのないものに感じられる。料 理とのペアリング，サービスの工夫などにより日本酒 のイメージをくっきりと明確に訴えていく必要がある だろう。

第三はスタンダードの問題。

フランス・ワインには風味の「標準」が存在してい る。ブドウの品種と作り手の所在地（テロワール）で だいたいの味わいをイメージできる。ソムリエという 沢山の引き出しを頭の中におさめた職業集団が成立し うるのは, テロワール毎に味わいの標準があるからだ。
どんな風味が飛び出してくるのか分からない日本酒は スリリングだが，味わいについての標準がないことは， 日本酒を購入するフランス人にとっては「厄介」に感 じられはずである。

\section{2. フランスの日本レストランと日本酒}

10 年来, フランスで日本食ブームが盛り上がった。 日本酒を飲むフランス人の数が増えるのではと期待し たくなるが, ことはさほど簡単ではない。

フランスでは,「日本食」レストランが 2000 年前後 から急増し，現在 1600 軒ほどあるらしい ${ }^{5}$ が，9 割 は非日本人系「スシ」店と推定される ${ }^{6}$ 。これらファ ーストフード的なスシ・レストランは安価な普段食の 場である。日常の「ケ」の食事でありフランス人はワ インも飲まないし，「冒険」して日本酒を飲もうとい うことにはなかなかならない。

一方，「本格的」日本レストランというのも変だが, オーナー（及び／又は）シェフが日本人のレストラン は，フランス全体で 100 軒強程度の少数派にとどまる。 ただし，「本格的」日本食への仏メディアの関心は高 くビジビリティーはあり，日本酒紹介の受け血として 効果が高い。フランス人の多くは日本食の食中飲料に ついて特別な考えを持っておらず，スタッフが自信を 持って勧めることができれば日本酒流布の媒介役とし て有効だろう。

日本食レストランのサービス・スタッフを対象にし た日本酒研修の仕組みが望まれる。

\section{3. フランチ・レストランと日本酒}

日本酒のプロモーションには, オピニオンリーダー に良さを分かってもらうことが重要だと考光, 有力シ エフ・ソムリエに日本酒ファンになってもらうよう, 以下のようなフレンチ・レストランで日本酒ディナ

5 「調查会社 GIRA コンセイユによると, 仏の「スシレストラン」の数は現在 1580 店に達した。ファストフー ド店（1750）と余り変わらないが，年商はスシレストランの 8 億 6400 万ユーロに対しファストフードは 45 億ユーロと両者の隔たりは大きい。大多数のスシレストランは独立系で, 1990 年代に大流行したネム（ベト ナム風春巻き）の人気低下を受けて，“金になるスシ”に転向した元中華レストランが多い。一方で，スシシ ヨップ, プラネットスシ, Sushiwest, などのチェーン店も台頭し, 2010 年末のチェーン店舗数は 132 , 売上 げは合計 1 億 4000 万ユーロに達した。なお GIRA コンセイユによると, スシ愛好者は大都市に住む, どちら かというと知的職業につく 45 才未満の層。」出典：AFP 2011-02-07

6 パリ首都圈について, 電話帳から数を拾う作業をしてみたところ, ほぼ 1000 軒の日本食レストランがあった が，その内，日本人が経営しているか，日本人の料理人がいる店の数は 100 軒弱でだいたい 1 割になった。 
ー・ランチを企画してきた。

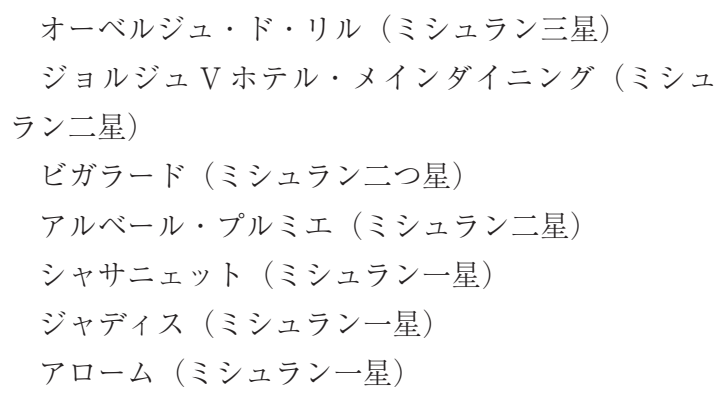

直近では, 9 月 3 日にパリのビストロ「シャトーブ リアン」で日本酒夕食会を開催した。

開催日： 2011 年 9 月 3 日（土）, 20 時から

開催地： レストランル・シャトーブリアン

Le Chateaubriand

住所： 129 Avenue Parmentier 75011 Paris

参加者； 52 名（有料 120 ユーロ／人）

【レストラン ル・シャトーブリアン】

パリの下町 11 区にあるレストラン ル・シャトーブ リアンは 1930 年代創業のワイン・ビストロ。エディ ット・ピアフが街角で歌っていた古き良き時代の面影 を残す。バスク地方出身のイナキ・エズピタルト料理 長による斬新なメニューが話題になり，2011年度の 世界ベストレストラン・ランキングで 9 位にノミネー トされた。ミシュランの星は 1 つ。

【メニューとマリアージュ】

1）宮坂醸造「やわらか純米」 トリュフと香草（フヌイユ）のアミューズ・ ブッシュ

2）楯の川酒造「濁流」 セビーチェ

3）大七酒造「箕輪門」 スパイス・ナッツでコーティングされた鴨の 心臟

4）南部美人「ALL KOJI 2008」 ペルセベス（亀の手）

5）出羽桜酒造「一路」 無とフォアグラのブイヨン
6）室町酒造「桃太郎卜マト酒」

リンゴのキューブ（セロリ風味）

7）大七酒造「真桜」

マグロの切り身と紫芋ピュレ

8）黑龍酒造「龍」

ポワローのイカスミ煮

9）旭酒造「獺祭 EU50」

白身魚グリル，

10）須藤本家「黒吟」

豚皮スフレと鮙のマリネ

11）油長酒造「風の森露葉風」

鰻のグリル

12）萬乗醉造「醉し人九平次純米吟醉」

牛肉タルタルステーキ (粉末酵母トッピング)

13）惣誉酒造「きもと純米大吟醉」

黒豚のプレサ, ハーブ風味

14）壱岐の蔵酒造 リキュール「柚子小町」

胡瓜の種，グリーンコーティング

15）須藤本家「超甘口」

キノコのチョコレート風味

16）旭酒造「3 割 9 分スパークリング」

アプリコットの蜂蜜煮タルタルステーキ

17）楯の川酒造「清流」

木いちご

食後酒として

18）京屋酒造 芋焼酎「侍舞（常圧）」

\section{【参加者】}

予約客 52 名とジャーナリス卜数名が参加し店内は 満席。

ホテルジョルジュ・サンクのエリック・ブリファー ル総料理長や人気ロックグループ, フェニックスのメ ンバー, ピエール・エルメ元夫人のフレデリック・グ ラス・エルメさん（料理研究家）の姿もあった。惣誉 酒造の河野社長, 出羽桜酒造の仲野部長が参加された。

\section{【ディナーの模様】}

開始直前に土砂降りの雨という悪天候のため, 遅れ て到着する参加者を待ちながら，拪酒と様々なおつま み（グジェール，ムール貝，海老など）が振る舞われ， 気さくな雲囲気で食事が始まった。15種類の日本酒と， 途中で口休め的に 2 種のリキュール，それぞれ合わせ 
た料理が計 17 種出て, 最後に焼酎。メニューの前半 はシェフの個性的なミニアチュール料理（一ロサイズ の料理）で，参加者はワイングラスでサービスされる 日本酒とのマリアージュを楽しんだ。イナキ・シェフ と若手実力派ソムリエのセバスチャン氏のタンデムが 作り上げたユニークなフレンチ・ビストロ料理と日本 酒との相性に参加者から驚きの声があがった。媣夜 12 時過ぎにディナーが終わった後も，ほとんどの参 加者が自分の気に入った拪酒をバーカウンターで再度 試飲。午前 1 時過ぎまで続き, 大盛況だった。また, ディナーに参加したジョルジュ V のエリック・ブリ ファール総料理長は, 秋・冬のメニューから日本酒を 取り入れたいと語っていた。

\section{4. 日本酒の対仏輸出}

過去 10 年間の日本酒対仏輸出の数字を見ると跛行 性があるが, フランスの経済成長率を反映した動きで ある。

ただし，単価を見ると逓増傾向にあり，特に 2007 年からかなりはっきり上昇している。2005 年の輸入 量·金額の数字を 4 合瓶換算すると, 1 本平均 360 円 だったものが，2010年には 518 円になっている。イ セによる吟醉, 大吟醸酒の輸入開始とタイミング的に 合致しており，フランスに於ける日本酒の「高級」化 にいくばくかでも貢献できたのではないかと密かに考
えている。

欧州日本酒市場（2010 年）でフランスは, 絶対量 で独英だけではなく, オランダ, イタリアより少なく 主要国中 5 位。ただし, 金額では 3 位で欧州市場のな かで高級酒比率が高いことが分かる。輸出量を金額で 割ると, 2010 年はフランスが $\mathrm{EU}$ 諸国中でトップ, イギリスがこれに次ぎ, 3 位のドイッ以下を大きく引 き離している。

$\mathrm{EU}$ 全域について輸入量を国の人口で割ると, 意外 な結果が見える。国民 1 人あたりの日本酒輸入量が最 大の国はラトビア（61リットル／人）になる。台湾 と比較できる水準でフランスの 31 倍。オランダも 11 リットル／人と米国とほぼ同じ水準でフランスのほぼ 9 倍を示している。

ラトビアは, ロシア, 北欧へのハブになっていること が予測され, オランダも欧州最大の海運基地を擁し, 他の欧洲諸国向けの中継基地になっていると推測され る。

仏日本酒市場が数量でイギリス並みの密度（輸入量 / 人口）になると, フランス市場は今の 2.6 倍になり， ほぼ 20 万リットル，4合瓶換算で現在より 28 万本近 い上乗せになるはず。伸びる可能性はまだまだある。

\section{対仏日本酒輸出と経済成長率}

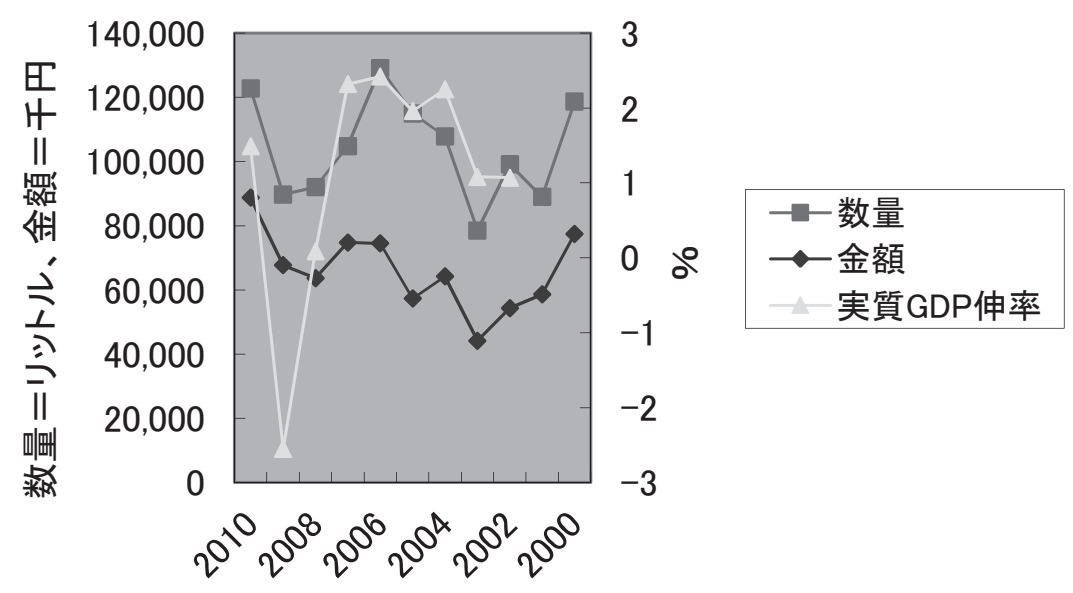

第 5 図対仏日本酒輸出と経済成長率

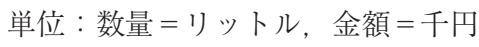

出所：通関統計 


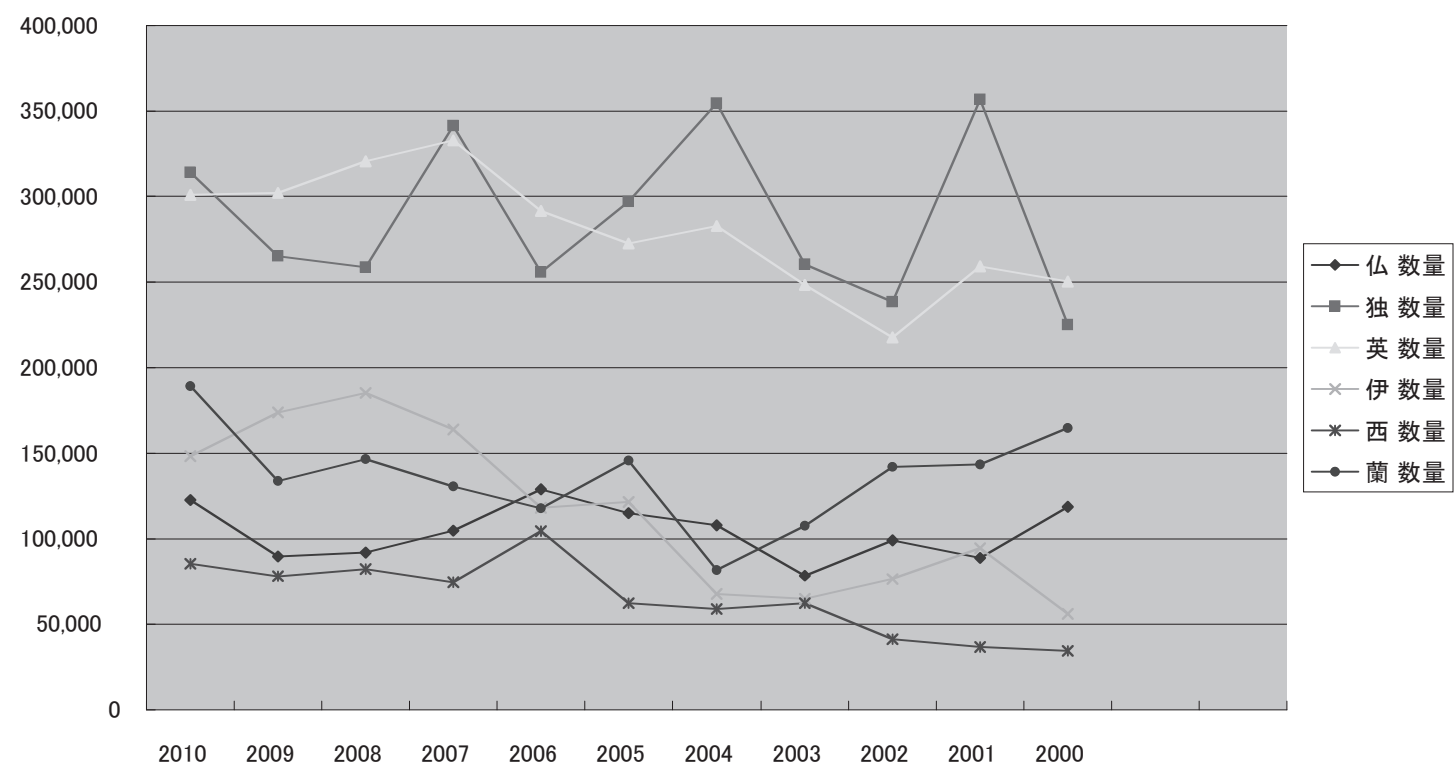

第 6 図 欧州主要国向け日本酒輸出 (数量)

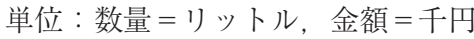

出所：通関統計

欧州主要国日本酒輸入金額

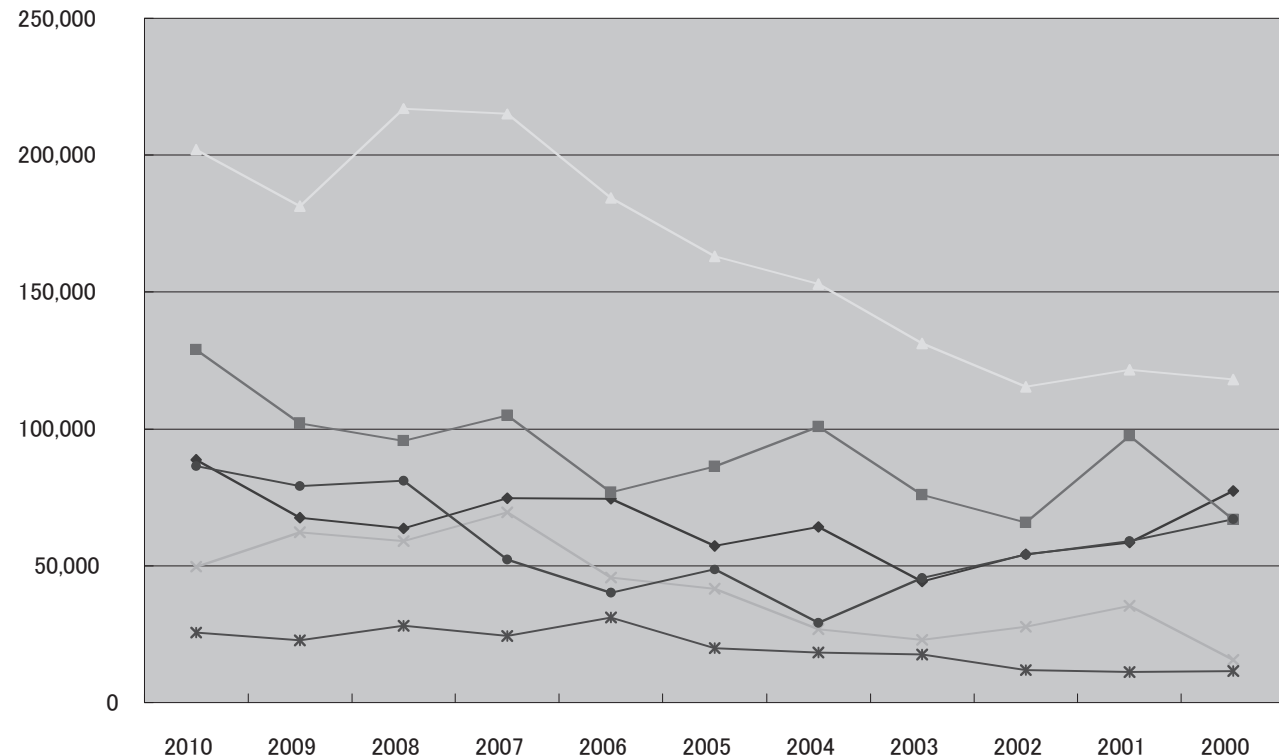

第 7 図欧州主要国向け日本酒輸出 (金額)

単位 : 数量 $=$ リットル, 金額 $=$ 千円

出所：通関統計 


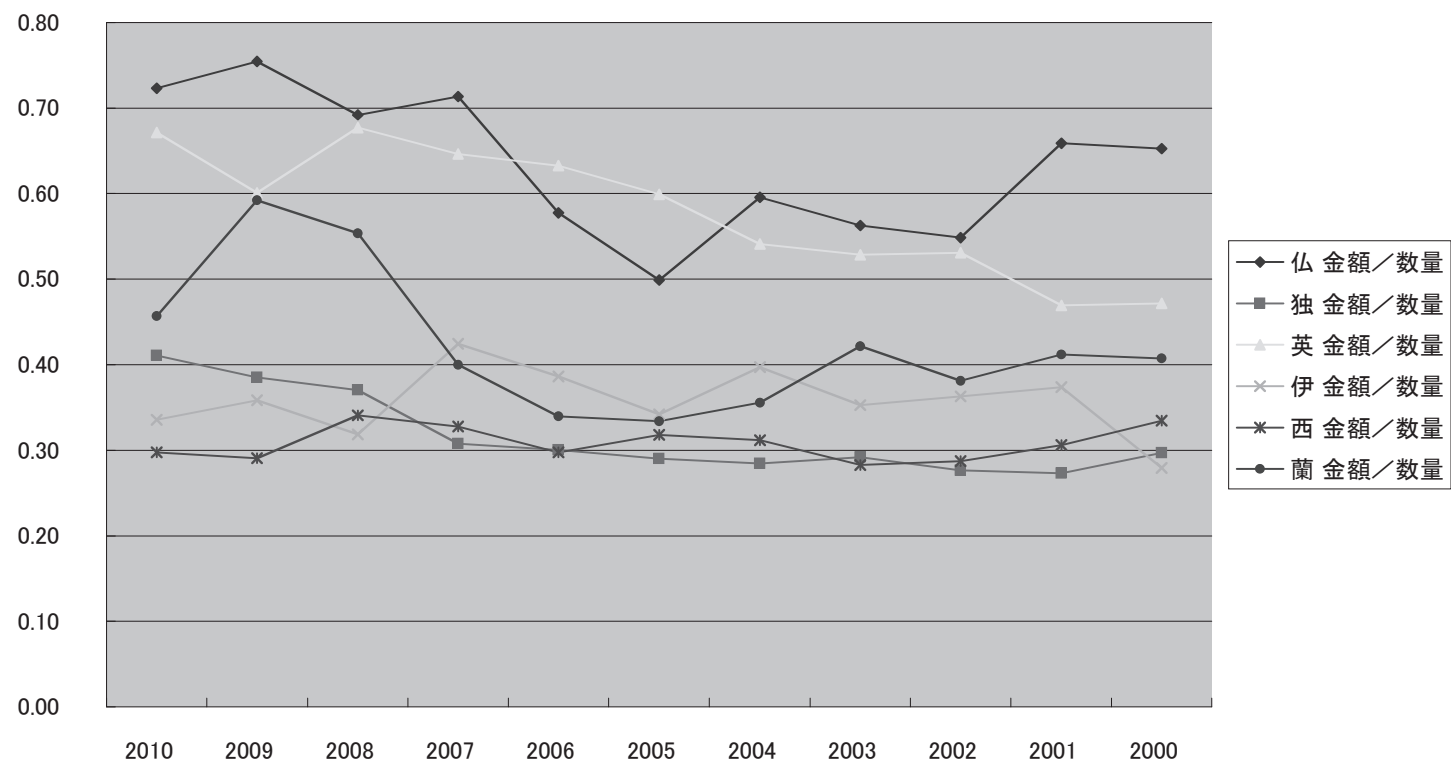

第 8 図 欧州主要国向け日本酒輸出 (単価)

単位：単価 $=$ 千円 / リットル

出所：通関統計

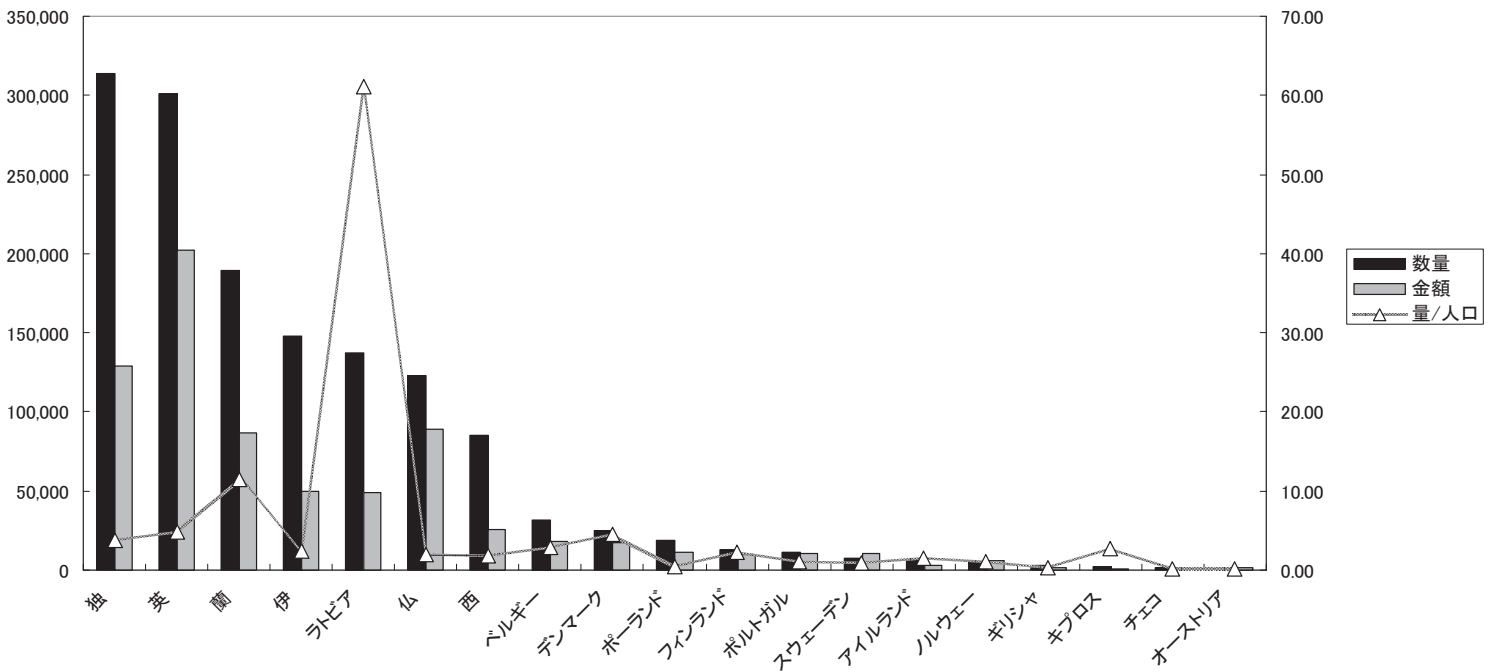

第 9 図欧州諸国への日本酒輸出 (数量)

単位：数量 $=$ リットル, 金額 $=$ 千円

出所：通関統計 
第 2 表 欧州諸国への日本酒輸出「数量／人口」

\begin{tabular}{|c|c|c|c|c|c|}
\hline & 数量 & 金額 & 金額/数量 & 数量／人口 & 金額 /人口 \\
\hline 台湾 & $1,639,266$ & 501,906 & 0.31 & 71.08 & 21.76 \\
\hline ラトビア & 137,307 & 48,661 & 0.35 & 61.07 & 21.64 \\
\hline 米国 & $3,705,385$ & $3,172,269$ & 0.86 & 11.78 & 10.08 \\
\hline 蘭 & 189,132 & 86,414 & 0.46 & 11.41 & 5.21 \\
\hline 英 & 300,758 & 201,810 & 0.67 & 4.85 & 3.25 \\
\hline デンマーク & 25,151 & 17,081 & 0.68 & 4.55 & 3.09 \\
\hline 独 & 313,833 & 128,920 & 0.41 & 3.84 & 1.58 \\
\hline ベルギー & 31,730 & 18,281 & 0.58 & 2.93 & 1.69 \\
\hline キプロス & 2,124 & 833 & 0.39 & 2.64 & 1.04 \\
\hline 伊 & 148,213 & 49,773 & 0.34 & 2.46 & 0.82 \\
\hline フィンランド & 12,468 & 9,574 & 0.77 & 2.33 & 1.79 \\
\hline 仏 & 122,718 & 88,754 & 0.72 & 1.95 & 1.41 \\
\hline 西 & 85,580 & 25,480 & 0.30 & 1.86 & 0.55 \\
\hline アイルランド & 6,752 & 3,076 & 0.46 & 1.51 & 0.69 \\
\hline ポルトガル & 10,965 & 10,438 & 0.95 & 1.03 & 0.98 \\
\hline ノルウェー & 4,910 & 6,196 & 1.26 & 1.01 & 1.28 \\
\hline スウェーデン & 7,844 & 10,435 & 1.33 & 0.84 & 1.12 \\
\hline ポーランド & 18,909 & 11,190 & 0.59 & 0.50 & 0.29 \\
\hline ギリシャ & 3,258 & 1,381 & 0.42 & 0.29 & 0.12 \\
\hline チェコ & 1,464 & 1,253 & 0.86 & 0.14 & 0.12 \\
\hline オーストリア & 999 & 1,181 & 1.18 & 0.12 & 0.14 \\
\hline
\end{tabular}

\section{おわりに}

一言, 放射線の問題について。

日本 (食) ブームは,「日本のものは良いもの」と いう漠然としてはいるが好意的なイメージが下支えし ていた。福島第一原子力発電所の事故によって，その 土台がもろくも崩落した。

原子力事故そのものの涾刻性もさることながら, 事 故後の日本からの説明, 情報発信（方法と内容）に疑 問，不信がもたれ，その帰結として日本食品（日本酒 も含めて）にも不信感が生まれている。

世界の人々が分かち合う大気, 海洋に有害な物質を
大量に放出してしまった以上, その有害性について可 能な限りの誠意をもって説明する責任を日本は負って いる。また，日本国内で生産される食品（日本酒を含 めて）はすべて，フランス人を含めて外国人にとって 「グレーな盧犯者」であることを認識しなければなら ない。普通の日本人が, 90 以上あるフランスの県の 名前を知らないように, フランス人も日本の地理には 疎い。「フクシマ」が日本の中にある以上, 外国から 見ると日本全体がフクシマなのだと認識するべきだ。

この状況下で，な拧「良い食品（日本酒）」をフラ ンス人，外国人に訴求するにはどうすれば良いのだろ うか。 
まず，暫定基準值は「安心の基準」になっていない ことを認めるべきだろう。筆者は, 暫定基準值と疫学 的安全性に付いて云々する知識を持ち合わせないが, 多くのフランス人と同様，基準值はきわめて苛烈な極 限状況で緊急避難的に設定されたものだろうと思って いる。科学的コンセンサスにかならずしも基づいてい ないのではないかという疑問が払拭できない。このよ うな懸念に根拠があるか否かは別にして，すでにフラ
ンスで（おそらくその他の諸外国で）懸念が広く流布 してしまっていることが重要だ。政府の基準より厳し い自主的基準の採用を発表した食品企業もでてきてい るが, これも一つの対応法だろう。日本からは, 3.11 以降も「安全で安心な良い食品（日本酒）を提供す る」という基本的メッセージを強く発信してもらいた w。

$\langle$ Issé \& Ciè

執筆者紹介（順不同・敬称略）

黒田利朗 $<$ Toshiro KURODA $>$

昭和 25 年 10 月 1 日生まれ<勤務先とその所在地> Issé \& Cie, 11 rue Saint Augustin 75002 Paris, France <略歴 $>$ 昭和 50 年パリ大学第 7 学部日本語学 科修了, 昭和 $59 \sim 62$ 年パリ大学第 7 学部日本語学科 講師, 昭和 56 年調査会社 KSM 設立, 社長に就任, 現在に至る。平成 15 年有限会社「イセ」を設立しレ ストラン「眉山」をパリで開業。平成 19 年イセ, 日 本酒・食材の輸入販売を開始。<抱負 $>$ 日本の良い食 品をフランス，ヨーロッパに伝えたい。<趣味＞酒と タバコ。

\section{高橋康次郎 $<$ Kojiro TAKAHASHI >}

昭和 17 年 1 月 13 日生まれ<勤務先とその所在地 $>$ 東京農業大学, 干156-8502 東京都世田谷区桜ヶ丘 1-1-1，日本酒造組合中央会 $\bar{\top} 105-0003$ 東京都港 区西新橋 1-1-21<略歴>昭和 40 年北海道大学農学部 農芸化学科卒, 農学博士。昭和 40 年国税庁入庁, 昭 和 62 年国税庁醸造試験所第 4 研究室長, 札幌 - 仙台 国税局鑑定官室長, 醸造研究所酒類理化学研究室長を 経て, 平成 9 年醸造研究所所長, 平成 10 年宝酒造(株) 入社, 11 年取締役酒類技術開発本部長, 17 年非常勤
参与, 18 年日本酒造組合中央会技術顧問, 19 年東京 農大醸造科学科教授, 現在に至る。<抱負 > 乳酸菌の 素晴らしい働きを利用した日本酒・焼酎の製造法を進 めたい。<趣味>史跡探訪, 小唄, 書道。

宮井孝一 $<$ Kouichi MIYAI $>$

大正 13 年 2 月 5 日生まれ 勤務先とその所在地 $>$ 于 142-0051 品川区平塚 3-13-18<略歴>昭和 19 年 廣島工専醗酵工業科（現広大工学部）卒, 同年 10 月 東京財務局鑑定部 (12 月財務局技手) 同 21 年大蔵技 官（同 23 年 6 月東京国税局鑑定官室）同 30 年 4 月鑑 定官, 同 31 年清酒の白ボケ矯正「柿渋・ゼラチン 法」を発案 (本誌 52 巻, 1 号, 1957), 同 43 年 6 月 ～熊本, 名古屋, 関信局主任鑑定官, 51 年 7 月～札 幌国税局鑑定官室長, 同 54 年 7 月退官, 同 54 年 8 月 ～ 63 年末の間「石川酒造 k.k, 武蔵野商事 k.k, （KK 武蔵野化学研究所), 日本地酒頒布協同組合等の技術 顧問」, 平成以降〜 19BY までは, 酒造技術アドバイ ザーとして清酒，乙焼酎，リキュール類の製造に関与。 $<$ 抱負 $>$ 酒造り 65 年余の回顧と日本酒の需要振興策。 <趣味>水墨画等の鑑賞, TV (スポーツ, 脳の活性 化等)。 